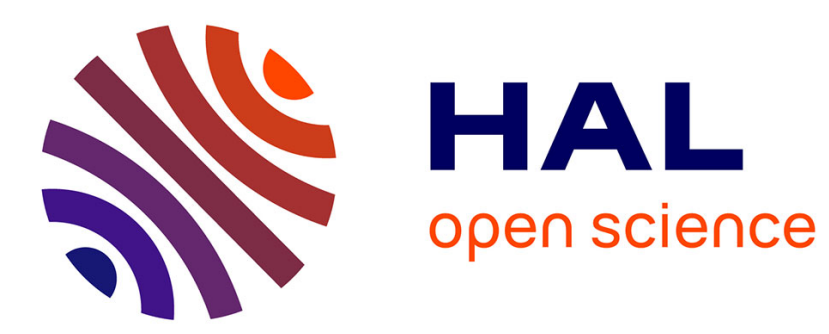

\title{
Adaptation of the geopolymer composite formulation binder to the shaping process
}

\author{
J. Archez, Nathalie Texier-Mandoki, Xavier Bourbon, Jean-François Caron, \\ Sylvie Rossignol
}

\section{- To cite this version:}

J. Archez, Nathalie Texier-Mandoki, Xavier Bourbon, Jean-François Caron, Sylvie Rossignol. Adaptation of the geopolymer composite formulation binder to the shaping process. Materials Today Communications, 2020, 25, pp.101501. 10.1016/j.mtcomm.2020.101501 . hal-02958583

\section{HAL Id: hal-02958583 \\ https://hal-unilim.archives-ouvertes.fr/hal-02958583}

Submitted on 3 Dec 2020

HAL is a multi-disciplinary open access archive for the deposit and dissemination of scientific research documents, whether they are published or not. The documents may come from teaching and research institutions in France or abroad, or from public or private research centers.
L'archive ouverte pluridisciplinaire HAL, est destinée au dépôt et à la diffusion de documents scientifiques de niveau recherche, publiés ou non, émanant des établissements d'enseignement et de recherche français ou étrangers, des laboratoires publics ou privés. 


\title{
Adaptation of the geopolymer composite formulation binder to
}

\section{the shaping process}

\author{
J. Archez ${ }^{1,2,3}$, N. Texier-Mandoki ${ }^{2}$, X. Bourbon ${ }^{2}$, J.F. Caron ${ }^{3}$ and S. Rossignol ${ }^{1}$ \\ ${ }^{1}$ IRCER: Institut de Recherche sur les Céramiques (UMR7315), 12 rue Atlantis, 87068 \\ Limoges, France. \\ ${ }^{2}$ Agence nationale pour la gestion des déchets radioactifs (Andra), 1/7 rue Jean-Monnet, 92298 \\ Chatenay-Malabry, France. \\ ${ }^{3}$ Laboratoire Navier, UMR 8205, Ecole des Ponts Paristech, CNRS, UPE, Champs-sur-Marne, \\ France
}

- Corresponding author: sylvie.rossignol@ unilim.fr, IRCER, 12 rue Atlantis, 87068 Limoges, France, tel.: 33587502564 .

\begin{abstract}
This work aims to adapt a formulation of a geopolymer composite to elaborate complex shapes. Here a hollow cylinder is chosen to investigate different possible solutions: building process according to the formulation. To this end, different content of metakaolin, wollastonite, and glass fibers was used to identify the feasibility of shaping of the geopolymer composites. Hollow cylinder shape was elaborated from different formulations by casting and additive manufacturing (robocasting or Direct Ink Writing) regarding their feasibility. The mechanical properties of the formulations were then analyzed with thermal analysis, compressive and flexural tests, and compared with their way of shaping. The results showed that the viscosity can be mainly controlled by the wollastonite content. The formulations adapted to the robocasting present an optimal mechanical resistance due to a higher amount of reinforcement elements. A formulation that can be cast and robocast has been obtained and presents a compressive strength of $89 \mathrm{MPa}$ and bending strength of $15 \mathrm{MPa}$. Thus, here some keys are
\end{abstract}


given to design a formulation of geopolymer composite adapted to a shaping process by modifying the metakaolin, wollastonite, and glass fiber content.

\section{Keywords}

Geopolymer, Composite, Shaping process, Casting, Additive manufacturing, Feasibility

\section{Funding}

This work was supported by the French National Radioactive Waste Management Agency (Andra) in collaboration with IRCER and Navier laboratories. 


\section{INTRODUCTION}

Cigéo is the radioactive waste disposal facility project led by the French National Radioactive Waste Management Agency (Andra). This deep geological disposal designed for long term management of the high and intermediate-level radioactive waste will be built in the east of the Parisian basin (France). The high-level radioactive waste cell concept is based on a steal liner inserted in a tunnel dug in geological medium, and whose primary function is mechanical to ensure safety, security, and retrievability during the operating phase. The use of geopolymers reinforced with inorganic elements could be an innovative solution for the liner to reduce metallic use in the project and meet the mechanical specifications.

Geopolymers are inorganic materials synthesized by dissolving an aluminosilicate source in a silicate alkaline solution $[1,2]$. The reactive mixture obtained is under a viscous liquid form until a fast setting phase. The setting time is depending on the formulation of the geopolymer (as a function of the alkaline solution [3, 4], the aluminosilicate source [5, 6] or the use of additives $[7,8,9])$. The setting is achieved at room temperature by polycondensation and geopolymerization reactions. Geopolymer materials present a wide range of mechanical properties: compressive strength between 10 to $110 \mathrm{MPa}$ and bending strength from 3 to 17 MPa depending on the formulation or reinforcements [10]. Geopolymers also exhibit high temperature resistance and chemical durability (acids) [11]. By-products can also be used as an aluminosilicate source $[12,13,14]$. As an example, argillite from the Callovo-Oxfordian layer (taken from the French underground level laboratory at Bure site) was used to make a grout $[15,16]$. In the literature, inorganic reinforcements such as basalt fibers $[17,18]$, glass fibers $[19,20]$, or wollastonite needles $[21,22]$ have been used with geopolymers or alkali-activated materials to reinforce the material and improve its ductility through controlled microcracking. The influence of wollastonite and glass fibers on geopolymerization reaction, viscosity, and mechanical properties of geopolymer composite have been studied previously to formulate 
geopolymer composites [23]. To shape these composites, a common process is to cast materials in molds $[24,25]$. Other processes can also be used such as mold pressing [26, 27, 28] or injection $[29,30]$. Low viscosity reactive mixture can also be sprayed as droplets using a spray gun $[31,32]$. Using this "spray technique", hollow cylinders have been produced with a low viscosity geopolymer onto a rotating cylindrical mold [33]. The addition of reinforcement leads to an increase in viscosity and consequently reduces the flowability of the material and its workability. In the presence of short or micrometric fibers, the decrease in flowability has been observed by Alomayri [34] and a maximum rate of $2 \%$ of fiber by volume was emitted. Moreover, Soliman et al. [35] observed a decrease of the concrete flowability up to $12 \%$ with the addition of $17 \% \mathrm{w}$ of wollastonite due to the interlocking of wollastonite needles. Vickers et al. [36] also observed a $53 \%$ decrease in flowability with the addition of $13 \%$ w of wollastonite.

High viscosity reactive mixtures can be shaped using other techniques such as extrusion or additive manufacturing with a robocasting (or Direct Ink Writing) process [3]. In these cases, the rheological properties of the reactive mixture must be controlled to allow a pumpability, a printability, and a buildability of the material with an adapted setting time $[37,38]$. The robocasting process has been used in the literature with alkali-activated composites [39] or with the addition of organic adjuvant such as poly(ethylenglycole) PEG or poly(acylic acid) PAA in geopolymers [40]. The authors studied the rheology of the geopolymers and shown that geopolymers could behave like Bingham fluid with a yield stress and a fast viscosity recovery after shear stress significant of a high shape retention after extrusion. This behavior makes geopolymer suitable to be used in additive manufacturing. The rheology is then commonly used to verify the extrudability of the composition in presence of several additives (plasticizers, adjuvants ...)[40, 41, 42]. The use of organic adjuvants to adapt the rheology is prohibited for our specific application. Another approach has here been chosen: without the rheology, but by 
studying the formulation (metakaolin, wollastonite, glass fibers) as a function of the way of shaping.

Some authors have already compared the difference in the mechanical behavior of the same composition produced by casting or robocasting with concrete $[43,44]$ or alkali-activated $[45$, 39]. An increase in bending mechanical resistance in the order of $14 \%$ was observed in robocasting compared to the casting process due to the orientation of the fibers perpendicular to the stress. These data must be linked to the manufacturing process. However, the presence of fibers during extrusion $[19,46]$, or the use of unsuitable parameters (extrusion speed and pressure, nozzle height) may cause the formation of voids [47], reduces the adhesion of the layers $[49,48]$ and therefore decrease the mechanical properties. To our knowledge, there is no use of a same geopolymer formulation that can be shaped by casting and robocasting or no studies allowing to adapt a formulation to different shaping processes without the use of organic adjuvants.

This work aims to determine a range of formulation adaptable to different shaping. For this, the feasibility of shaping of different geopolymer composite formulation was studied by varying the amount of metakaolin, wollastonite, and glass fibers. The geopolymer composites were then shaped by casting and robocasting and the properties of the formulations were compared to their feasibility of shaping.

\section{EXPERIMENTAL}

\section{Raw materials and samples preparation}

To elaborate on the geopolymer composites, the reactive mixture is obtained by dissolving a commercial metakaolin provided by Imerys called $\mathrm{M} 1(\mathrm{Si} / \mathrm{Al}=1.17)$ in a commercial potassium silicate solution supplied by Woellner called $\mathrm{S} 3([\mathrm{~K}]=7 \mathrm{~mol} / \mathrm{L})$. After homogenization (3 minutes), inorganic reinforcement elements such as wollastonite and short glass fibers were added and the total mixing time was ten minutes. The wollastonite is acicular 
particles $(\mathrm{L} .=5-170 \mu \mathrm{m}, \mathrm{D} .=3-15 \mu \mathrm{m})$ provided by Imerys, and glass fibers are alkali resistant (L. $=6 \mathrm{~mm}, \mathrm{D} .=13-15 \mu \mathrm{m})$ supplied by Owens Corning.

The nomenclature used is $\mathrm{M}_{\mathrm{x}} \mathrm{W}_{\mathrm{y}} \mathrm{G}_{\mathrm{z}}$, where $\mathrm{M}, \mathrm{W}$, and $\mathrm{G}$ stand for the Metakaolin, the Wollastonite and the Glass fibers respectively, whereas $x$ refers to the quantity of metakaolin in grams added in 15,6 $\mathrm{g}$ of alkaline solution $\mathrm{S} 3$ and $\mathrm{y}, \mathrm{z}$ represent the weight percentage of wollastonite and glass fibers respectively, relative to the mass of the binder $(\mathrm{S} 3+\mathrm{M} 1)$. As an example, for 15,6 $\mathrm{g}$ of solution S3, $16 \mathrm{~g}$ of metakaolin M1, 3.16 g of wollastonite $\mathrm{W}$, and 0.63 $\mathrm{g}$ of glass fibers $\mathrm{G}$, the composite will be referenced as $\mathrm{M}_{16} \mathrm{~W}_{10} \mathrm{G}_{2}$. The wollastonite and the glass fibers were added in two geopolymer binders ( $\mathrm{M}_{16}$ and $\left.\mathrm{M}_{19}\right)$ that had, respectively, a ratio $\mathrm{n}_{\mathrm{Si}} / \mathrm{n}_{\mathrm{Al}}$ equal to 1,55 and 1,49 and a ratio $\mathrm{n}_{\mathrm{K}} / \mathrm{n}_{\mathrm{H} 2 \mathrm{O}}$ equal to 0,141 .

\section{Process of fabrication}

The reactive mixture is cast in a closed mold or used by additive manufacturing (Figure 1). The casting is realized by pouring the reactive mixture in cylindrical mold $(\Phi=15 \mathrm{~mm}, \mathrm{H}=30$ $\mathrm{mm}, \mathrm{e}=10 \mathrm{~mm}$ ) (Figure 1-a). The mold is then placed on a vibrating table $(50 \mathrm{~Hz})$ for five minutes. The cylinder was unmolded when the reactive mixture started to present a mechanical resistance (around $12 \mathrm{~h}$ ). The central part is first removed then the piece is extracted using a piston.

The additive manufactured samples are elaborated by robocasting with a 3D Potterbot printer and the printing path (gcode) is coded with Rhinoceros/Grasshopper software (Figure 1-b). To print on a large scale, the reactive mixture is extruded through a large nozzle of $10 \mathrm{~mm}$. The flow is set up manually during the printing to maintain a layer width of $10 \mathrm{~mm}$ with a nozzle speed of $3 \mathrm{~mm} / \mathrm{s}$. A layer height of $6,5 \mathrm{~mm}$ is used to press and deform the new layer on the underneath layer and to ensure a better contact area and interface between the layers $[49,50]$. The temperature could have been adapted for the process, however, a temperature had to be optimized for each formulation [51]. In order to compare the formulations, the process was then 
carried out at room temperature. The consolidated material cast or printed is finally stored in a climatic chamber at $20{ }^{\circ} \mathrm{C}$ and $85 \% \mathrm{RH}$ with a saline solution of $\mathrm{KCl}$.

\section{Sample characterization}

The viscosity measurements of the reactive mixture are carried out on a Brookfield DV-II viscometer (with an estimated error of $1 \%$ ) on $60 \mathrm{~cm}^{3}$ of the reactive mixture in a cylindrical container twenty minutes after mixing the raw materials. To override the thixotropic effect and compare the measurements, the average viscosity value is determined over a one-minute measurement with a spindle LV4 -64. The spindle's speed is set up according to the viscosity, with values ranging from 0.1 to $100 \mathrm{rpm}$. The maximum viscosity value measurable is 6000 $\mathrm{Pa} \cdot \mathrm{s}$.

Differential Thermal Analysis (DTA) and Thermogravimetric Analysis (TGA) are carried out on an SDT Q600 apparatus from TA Instruments, using Pt/Pt - $10 \% \mathrm{Rh}$ thermocouples under a flowing dry-air atmosphere $\left(100 \mathrm{~cm}^{3} / \mathrm{min}\right)$. The powder samples were stored at $20^{\circ} \mathrm{C}$ and $85 \%$ relative humidity, and then heated up in platinum crucibles to $500{ }^{\circ} \mathrm{C}$ with a $5^{\circ} \mathrm{C} \cdot \mathrm{min}^{-1}$ heating slope.

The compressive tests were realized on six cylindrical samples $(\Phi=15 \mathrm{~mm}, \mathrm{H}=30 \mathrm{~mm})$ for each composition after seven days of consolidation. The cylindrical samples were rectified and tested using an Instron 5969, at a constant speed of $0.5 \mathrm{~mm} \cdot \mathrm{min}^{-1}$ with a load cell of $50 \mathrm{kN}$.

Three-point bending tests were carried out on six prismatic samples $(20 \times 20 \times 100 \mathrm{~mm})$ with an Instron 6022 apparatus, a span of $60 \mathrm{~mm}$, a constant speed of $5 \mu \mathrm{m} \cdot \mathrm{min}^{-1}$, and a load cell of $10 \mathrm{kN}$. The strains have been measured with strain gauges (Model KFGS-5-120-C1-11, Kyowa Electronic Instruments) centered under the sample, where the strain is maximum. The Young's modulus is determined by measuring the slope at the origin of the stress/strain curve. 


\section{RESULTS}

\section{Determination of the feasibility of shaping}

The shaping feasibility of reactive mixtures was first studied according to different metakaolin, wollastonite, and glass fibers content. Different compositions have been observed visually from the reactive mixture extruded with a syringe $\left(\Phi_{\text {nozzle }}=20 \mathrm{~mm} /\right.$ manual pressure $)$. Pictures of the feasibility tests for four compositions $\mathrm{M}_{\mathrm{x}} \mathrm{W}_{\mathrm{y}}$ (with $\mathrm{x}=10,14,16,19 \mathrm{~g}$ ) are presented in the Table 1. Whatever the formulation, the same behaviour is observed: the viscosity of the reactive mixture increases with the addition of wollastonite. The formulation $\mathrm{M}_{10} \mathrm{~W}_{\mathrm{y}}$ is not very viscous for " $y$ " less than $53 \% \mathrm{w}\left(\eta_{\mathrm{i}}<3900 \mathrm{~Pa} \cdot \mathrm{s}\right)$ and flows after being extruded. For an " $y$ " value ranging from 53 to $65 \% \mathrm{w}\left(3900 \leq \eta_{\mathrm{i}}\right)$, the geopolymer retains its shape after extrusion. For a high mass percentage of wollastonite $(y>65 \% \mathrm{w})$, the material is too viscous to be extruded with manual pressure. When using a higher amount of metakaolin $\left(\mathrm{M}_{14} \mathrm{~W}_{\mathrm{y}}, \mathrm{M}_{16} \mathrm{~W}_{\mathrm{y}}\right.$ et $\left.\mathrm{M}_{19} \mathrm{~W}_{\mathrm{y}}\right)$, the value of “ $y$ ” required to reach the extrusion domain decreases (33\%w, $19 \% \mathrm{w}$, and $8 \% \mathrm{w}$ respectively).

Thanks to these tests, the shaping domains have been reported in ternary diagrams in moles of aluminum (coming from the metakaolin), wollastonite, and glass fibers with $\mathrm{M}_{16} \mathrm{~W}_{\mathrm{y}} \mathrm{G}_{\mathrm{z}}$ and $\mathrm{M}_{19} \mathrm{~W}_{\mathrm{y}} \mathrm{G}_{\mathrm{z}}$ compositions are presented in Figure 2. The moles of aluminum have been chosen because, as shown in previous studies [23], the aluminum concentration controls the viscosity and mechanical properties of the geopolymer composite. In order to study the formulations according to their domain of shaping, eight compositions were selected in the ternary diagrams. The geopolymer binders (a0: $\mathbf{M}_{16}$ and $\mathbf{a 0}$ ': $\mathbf{M}_{19}$ ) belonging to the casting domain are the compositions of reference. The addition of wollastonite and glass fibers provides castable compositions (a: $\mathrm{M}_{16} \mathrm{~W}_{2} \mathrm{G}_{2}$ et $\mathbf{a}$ ': $\mathrm{M}_{19} \mathrm{~W}_{0.5} \mathrm{G}_{2}$ ). Two compositions were selected at the boundary between the casted and extruded domain (mixed domain) (b: $\mathrm{M}_{16} \mathrm{~W}_{10} \mathrm{G}_{2}$ et $\mathbf{b}^{\prime}: \mathrm{M}_{19} \mathrm{~W}_{2} \mathrm{G}_{2}$ ) and two formulations belong to the extruded domain (c: $\mathrm{M}_{16} \mathrm{~W}_{21} \mathrm{G}_{2}$ et $\mathbf{c}$ ': $\mathrm{M}_{19} \mathrm{~W}_{10} \mathrm{G}_{2}$ ). The addition 
of reinforcements allows determining domains of shaping feasibility (casting, extruded, and non-extruded) reported in the ternary diagrams based on molar percentages of aluminum, wollastonite, and glass fibers. The shaping domains evolve with the metakaolin content. In particular, the castable domain decreases with an increase of the metakaolin content $(\mathrm{x}=19 \mathrm{~g})$. The compositions $\mathrm{M}_{16} \mathrm{~W}_{\mathrm{y}} \mathrm{G}_{\mathrm{z}}$ (Figure 2-a) have a large castable domain meaning that a large amount of wollastonite and glass fibers can be added while maintaining the castability of the composition. On the other hand, the extrusion domain exists only for a large amount of wollastonite and / or glass fibers. Such amounts also affect the aspect and homogeneity of the extruded material (texture, cluster of fibers). When the metakaolin amount increases $(\mathrm{x}=19 \mathrm{~g}$ Figure 2-b), the binder viscosity increases and the castable domain decreases at the expense of the extrusion domain. As can be seen, it is possible to determine the castable and extrusion domains of the geopolymer composites depending on the metakaolin, wollastonite, and glass fibers amount. The results obtained with the formulations a0', a', b', c' will be used in the discussion part.

\section{Shaping}

In order to verify their shaping feasibility, the compositions $a 0, a, b, c$ have been cast in molds and shaped by additive manufacturing to form a hollow cylinder. The photos of the shaping as well as the viscosity of the compositions are displayed in the Table 2. Some compositions could be elaborated with a casting process but not with a robocasting process and vice versa. The geopolymer binder $\mathrm{M}_{16}$, with lower viscosity $(\eta=23 \mathrm{~Pa} \cdot \mathrm{s})$ could be shaped by casting and has a smooth surface appearance without cracks. However, the low viscosity of this composition does not allow a shaping by robocasting since the layers collapse entirely under the weight of the upper layers. A slight increase in viscosity by the addition of wollastonite and glass fibers $\left(\mathrm{M}_{16} \mathrm{~W}_{2} \mathrm{G}_{2}, \eta=148 \mathrm{~Pa} \cdot \mathrm{s}\right)$ allows obtaining the same shaping results. For an even higher viscosity and wollastonite content (composition $\mathrm{M}_{16} \mathrm{~W}_{10} \mathrm{G}_{2}, \eta=800 \mathrm{~Pa} \cdot \mathrm{s}$ ), the reactive 
mixture could be shaped by casting but present defects (air bubbles) related to the high viscosity of the reactive mixture. This composition can be shaped by robocasting but shows a slight settlement of the lower layers (sagging ratio $\left(\mathrm{h}_{\text {code }}-\mathrm{h}_{\text {layers }}\right) / \mathrm{h}_{\text {code }}$ equals to $\left.33 \%\right)$. With more wollastonite, the viscosity is even higher $\left(\mathrm{M}_{16} \mathrm{~W}_{21} \mathrm{G}_{2}, \eta>6000 \mathrm{~Pa} \cdot \mathrm{s}\right.$. $)$ and this composition can only be shaped by robocasting and present a lower settlement (sagging ratio equals to $21 \%$ ). The addition of reinforcement consequently increases the viscosity of the reactive mixture and modifies the feasibility of shaping. A low viscosity composition is preferable to be used in casting while a high viscosity composition can be used in additive manufacturing. Some compositions with intermediate viscosity $\left(\mathrm{M}_{16} \mathrm{~W}_{10} \mathrm{G}_{2}\right)$ can be elaborated by casting and robocasting but are not optimal and show defects. These data confirm the feasibility of shaping domains observed with a syringe and underline that the choice of shaping must be adapted to the viscosity of the composition and vice versa. It is important to note that the extrudable compositions are hardly castable to elaborate complex molds (hard to cast and presence of bubbles) but could be cast to elaborate compressive and flexural specimens without defects thanks to the use of a vibrating table.

\section{Impact of the formulations on the mechanical properties}

First, the results of the thermal analysis and the evaluation of the mechanical properties will be compared. Data relating to the formulations of the ternary $\left(\mathbf{a}: \mathrm{M}_{16} \mathrm{~W}_{2} \mathrm{G}_{2}, \mathbf{b}: \mathrm{M}_{16} \mathrm{~W}_{10} \mathrm{G}_{2}\right.$ et $\mathbf{c}$ : $\mathrm{M}_{16} \mathrm{~W}_{21} \mathrm{G}_{2}$ ) are presented in Figures 3 and 4. The curves of thermal analysis (DTA-TGA) of compositions a, b and c (Figure 3) display the same trend with different weight loss values. The weight loss between 25 and $200{ }^{\circ} \mathrm{C}$, associated with the endothermic profile, is characteristic of the water loss of geopolymers [52] respectively assigned to physisorbed water $\left(25-42{ }^{\circ} \mathrm{C}\right)$, to poral water $\left(42\right.$ and $\left.200^{\circ} \mathrm{C}\right)$ and structural water $\left(200-500^{\circ} \mathrm{C}\right)$. The castable composition $\mathrm{M}_{16} \mathrm{~W}_{2} \mathrm{G}_{2}$ (Figure 3 -a) shows a weight loss value $\left(42-500{ }^{\circ} \mathrm{C}\right)$ of $21 \%$ which gradually decreases to 20 and $17 \%$ for the compositions $\mathrm{M}_{16} \mathrm{~W}_{10} \mathrm{G}_{2}$ et $\mathrm{M}_{16} \mathrm{~W}_{21} \mathrm{G}_{2}$ (Figure 3 -bc). This is 
due to the modification of the polycondensation reactions induced by the addition of wollastonite and glass fibers $[6,23]$. The lower mass loss is due to the kinetics of the promoted polycondensation reactions in the presence of a high wollastonite content. These data underline that the transition from a casting composition to an extrusion composition induces modifications of networks formed on a local scale.

The compression and bending stress/strain curves of these same formulations are presented in Figure 4. The different compositions were poured into cylindrical polystyrene tubes and prismatic silicone molds using a vibrating table in order to respectively produce compression and bending specimens. The compositions exhibit brittle fractures in compression and ductile or brittle fracture in bending but also different maximum stress values. The composition $\mathrm{M}_{16} \mathrm{~W}_{2} \mathrm{G}_{2}$ has maximum compressive stress of $83 \pm 2 \mathrm{MPa}$. As seen previously, the wollastonite content increases the maximum stress values which are equal to 89 and $99 \mathrm{MPa}$ respectively for the composition $\mathrm{M}_{16} \mathrm{~W}_{10} \mathrm{G}_{2}$ et $\mathrm{M}_{16} \mathrm{~W}_{21} \mathrm{G}_{2}$. The data relating to the bending stresses present the same variations. The flexural strength of the formulation $\mathrm{M}_{16} \mathrm{~W}_{2} \mathrm{G}_{2}$ is equal to $13 \pm 1 \mathrm{MPa}$ and exhibits a ductile fracture. The addition of wollastonite induces an increase of 15 to $18 \mathrm{MPa}$ respectively for the formulations $\mathrm{M}_{16} \mathrm{~W}_{10} \mathrm{G}_{2}, \mathrm{M}_{16} \mathrm{~W}_{21} \mathrm{G}_{2}$. The fragile behaviour can be explained by an increase in the stiffness of the material. The castable composition $\left(\mathrm{M}_{16} \mathrm{~W}_{2} \mathrm{G}_{2}\right)$ presents indeed a Young modulus of $11 \pm 1 \mathrm{GPa}$. This value increases slightly with the wollastonite content to reach $15 \mathrm{GPa}$ for the composition $\mathrm{M}_{16} \mathrm{~W}_{21} \mathrm{G}_{2}$.

The formulations belonging to the extrudable domain have a higher mechanical resistance than the formulations of the castable domain due to a higher amount of reinforcements. The shaping by robocasting consequently allows using compositions that are more heavily loaded and which have greater mechanical properties. As shown in the Figure 1 of supplementary files, it can be noted that the process can induce slightly the mechanical properties between the specimens elaborated by casting or robocasting. The differences are caused by the orientation 
of fibers during the process (as shown in the Figure 2 of supplementary files) and by the presence of defects caused by the robocasting process. However, it won't be discussed in this paper as all the specimens were cast in mold thanks to the use of a vibrating table.

\section{DISCUSSION}

The different results showed that there exist different domains of shaping (casting/robocasting) depending on the formulation of the geopolymer composite and inducing different mechanical properties. This part deals with discussing the formulation parameters influencing the shaping and the induced mechanical properties.

In order to determine the formulation parameters influencing the shaping, the mass loss values $\left(42-500{ }^{\circ} \mathrm{C}\right)$ have been plotted as a function of the aluminum concentration for the formulations a0, a0', a, a', b, b' and c, c' (Figure 5). Water loss is directly linked to polycondensation reactions inducing the mechanical properties of the geopolymer [7, 4]. Aluminum concentration was chosen because it takes into account the metakaolin and the amount of the reinforcement. The concentration of aluminum increases with the addition of metakaolin and decreases with the addition of reinforcements. The same trend is observed depending on the metakaolin amount: an increase of the aluminum concentration leads to an increasing in the water loss observed with thermal analysis and a decrease of the mechanical properties of the consolidated material. Formulations with more metakaolin (a0', a', b', c') can be shaped by casting and additive manufacturing on a greater variation of aluminum concentration. Thus, a formulation heavily loaded with metakaolin and with fewer reinforcement elements (c': $\mathrm{M}_{19} \mathrm{~W}_{10} \mathrm{G}_{2}$ ) allows obtaining similar mechanical strength (100 $\mathrm{MPa}$ ) than a formulation weakly charged in metakaolin with more reinforcement elements (c: $\mathrm{M}_{16} \mathrm{~W}_{21} \mathrm{G}_{2}$ ). In addition, formulations with similar aluminum concentration (a: $[\mathrm{Al}]=7,5 \mathrm{~mol} / \mathrm{L}$ and c': $[\mathrm{Al}]=7,6 \mathrm{~mol} / \mathrm{L})$ but different métakaolin amount $(16$ and $19 \mathrm{~g})$ exhibit different mechanical properties ( 83 et $100 \mathrm{MPa}$ ) and different way of shaping. The compositions that can 
be cast or extruded have similar mechanical properties linked to a quantity of metakaolin and different reinforcements.

The relationship between the fresh state properties (viscosity), that condition the shaping, and the requirement of the consolidated state (mechanical properties) have also be checked. The viscosity values of the composition $\mathrm{a} 0, \mathrm{a}, \mathrm{b}$ and $\mathrm{c}$ have been plotted as a function of the resistance values in compression and bending. (Figure 6). The two shaping areas and their limits are also reported. The maximum viscosity of $6000 \mathrm{~Pa} \cdot \mathrm{s}$ corresponds to the measurement limits of the viscometer. The compression and bending mechanical properties evolve similarly according to these domains of shaping: they are weaker for lower viscosities (castable domain) and stronger for higher viscosities (extrusion domain). Reactive mixtures with no or little reinforcements $\left(\mathrm{M}_{16}, \mathrm{M}_{16} \mathrm{~W}_{2} \mathrm{G}_{2}\right)$ can be used in casting due to their low viscosity and has compressive mechanical strengths of 71 and $89 \mathrm{MPa}$. These values are in the range of mechanical properties of geopolymers (from 10 to $110 \mathrm{MPa}$ [10]). A higher amount of wollastonite increases the viscosity of the reactive mixture and allows it to obtain a composition $\left(\mathrm{M}_{16} \mathrm{~W}_{10} \mathrm{G}_{2}\right)$ castable and extrudable with satisfactory mechanical properties (89 $\left.\mathrm{MPa}\right)$. In comparison, Panda et al. [39] and Paul et al. [45] obtain respectively maximum compressive strengths of $35 \mathrm{MPa}$ at 28 days and $58 \mathrm{MPa}$ at 21 days using alkali-activated materials which are both castable and extrudable. An additional amount of wollastonite $\left(\mathrm{M}_{16} \mathrm{~W}_{10} \mathrm{G}_{2}\right)$ induces an increase of the mechanical properties $(99 \mathrm{MPa})$ and allows to use the robocasting process. These values are high compared to the materials usually used in robocasting. For example, Bong et al. [53] and Kashani et al. [54] used alkali-activated materials adapted to the robocasting process which present maximum compressive stresses in compression of 17 and $58 \mathrm{MPa}$ respectively. To our knowledge, no value is listed for extrudable geopolymers. The amount of wollastonite consequently permits to choose the shaping process (casting or robocasting) while controlling the mechanical properties of the consolidated material. Moreover, the robocasting process 
permits to use of compositions that are more heavily loaded and have higher mechanical properties than the casting process.

In order to compare these data and those of the literature, the reinforcement amounts (\%w) of glass fibers and wollastonite from previous work on cement $[35,55,56,57]$ alkali-activated materials $[19,36,58,59,60]$ and geopolymers $[61,62]$ were compared with the domains of shaping of the composite $\mathrm{M}_{16} \mathrm{~W}_{\mathrm{y}} \mathrm{G}_{\mathrm{z}}$ (Figure 7). The compositions of the literature are mainly located in the castable or mixed domains. Glass fibers have been used up to a maximum of 5 $\% \mathrm{w}$ [19] corresponding to the extrusion domain. Wollastonite has been used up to $19 \% \mathrm{w}$ [55] (excepted for Ransinchung et al. [56] that used up to $43 \% \mathrm{w}$ of wollastonite with a particle size of $4 \mu \mathrm{m}$, smaller than the cement particles, increasing the workability [35]). The compositions used in this study $(\mathrm{a} 0, \mathrm{a}, \mathrm{b}, \mathrm{c})$ have a glass fiber content of the same order of magnitude as the data observed in the literature while staying below a critical threshold to limit the formation of voids and balls of fibers [63, 64]. Moreover, compositions used in the extrudable domain (c, c') are more heavily loaded with wollastonite than the data in the literature. However, the extrusion domain depends on the nozzle diameter: the percentage of glass fibers must remain below the critical threshold to keep the material extrudable. This threshold was here equal to $7 \% \mathrm{w}$ with the $\mathrm{M}_{16}$ composition and a $20 \mathrm{~mm}$ nozzle). As a result, the robocasting process makes it possible to use compositions having higher mechanical properties linked to a greater quantity of reinforcements inserted.

\section{CONCLUSION}

This study focuses on the determination of a range of formulation for geopolymer composites to use with different shaping processes. The shaping feasibility for different composite formulations was first studied by varying the amount of metakaolin and wollastonite and/or glass fibers as reinforcements. The geopolymer composites were then shaped by casting and by robocasting. The mechanical properties of the formulations were compared. 
It has been possible to:

- control the viscosity of the reactive blend by adding wollastonite,

- shape hollow cylinders by casting and robocasting with accurate formulations,

- map mechanical properties according to the shaping process with an optimum for extruded formulations linked to a higher amount of reinforcement elements,

- obtain a castable and extrudable formulation with $\sigma_{\text {compression }}=89 \mathrm{MPa}$ and $\sigma_{\text {bending }}=15$ MPa.

In future work, the different formulations could be shaped, at the full scale by casting or robocasting, in the function of their shaping feasibility, to elaborate high-level nuclear waste cell liner. 
(a)

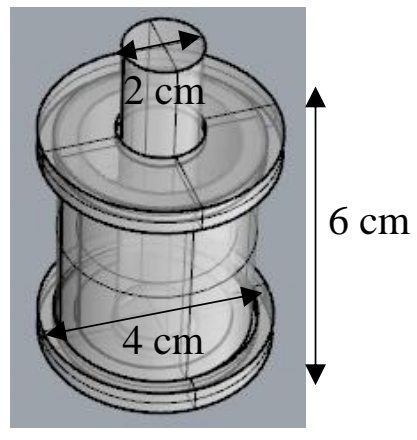

(b)

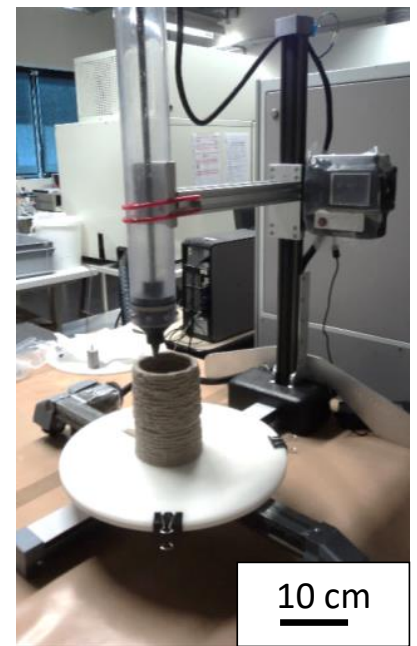

Figure 1: (a) characteristics of the mold used to make hollow cylindrical parts by casting and (b) 3D printer (3D Potterbot) used to make robocasting. 
(a)

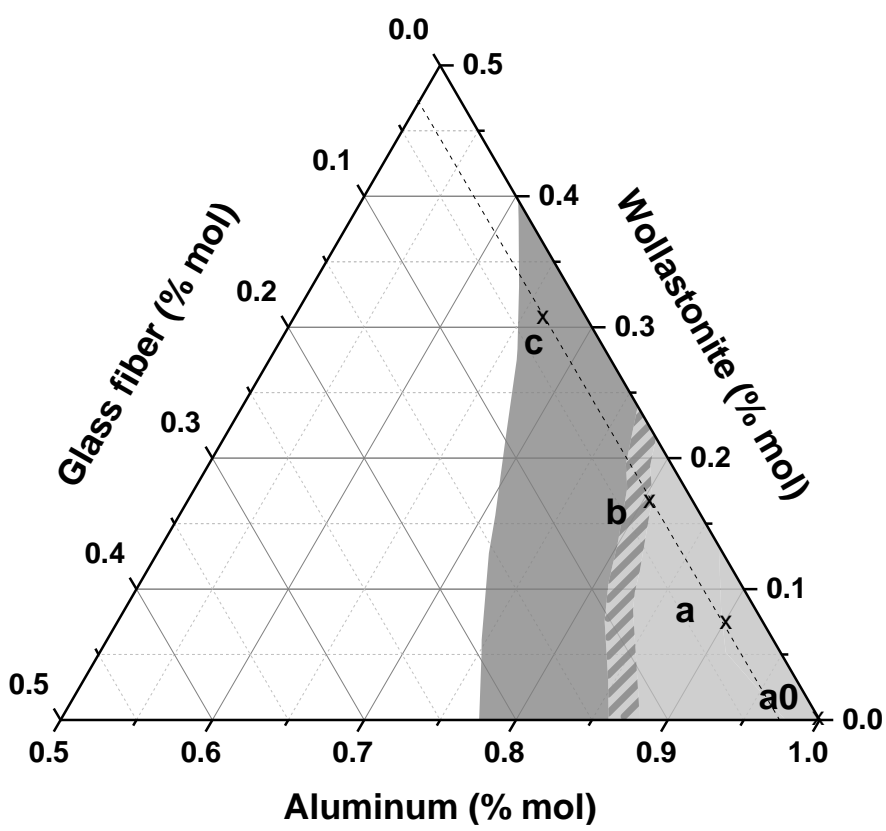

(b)

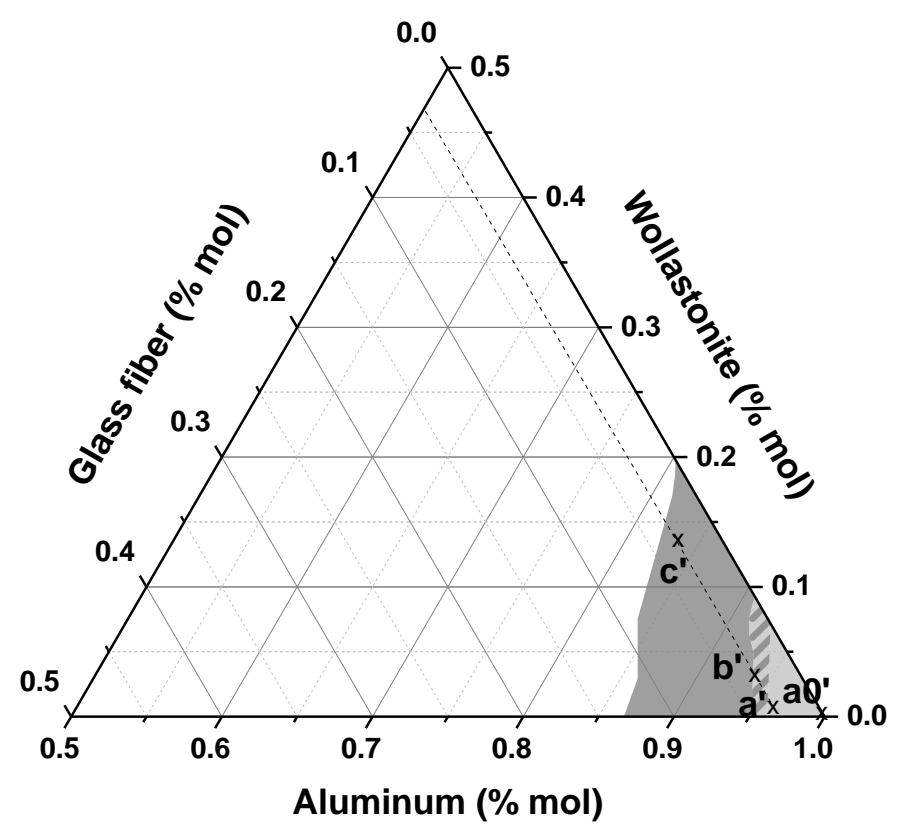

Figure 2: selected formulations in the ternary diagram in mol (Al, W, G) relative to (a) $\mathrm{M}_{16} \mathrm{~W}_{\mathrm{y}} \mathrm{G}_{\mathrm{z}}(\mathrm{a} 0, \mathrm{a}, \mathrm{b}, \mathrm{c})$ and (b) $\mathrm{M}_{19} \mathrm{~W}_{\mathrm{y}} \mathrm{G}_{\mathrm{z}}\left(\mathrm{a} 0\right.$ ', $\left.\mathrm{a}^{\prime}, \mathrm{b}^{\prime}, \mathrm{c}^{\prime}\right)$ with the representation of the feasibility for a $\square$ casting or an $\square$ extrusion shaping. 
(a)

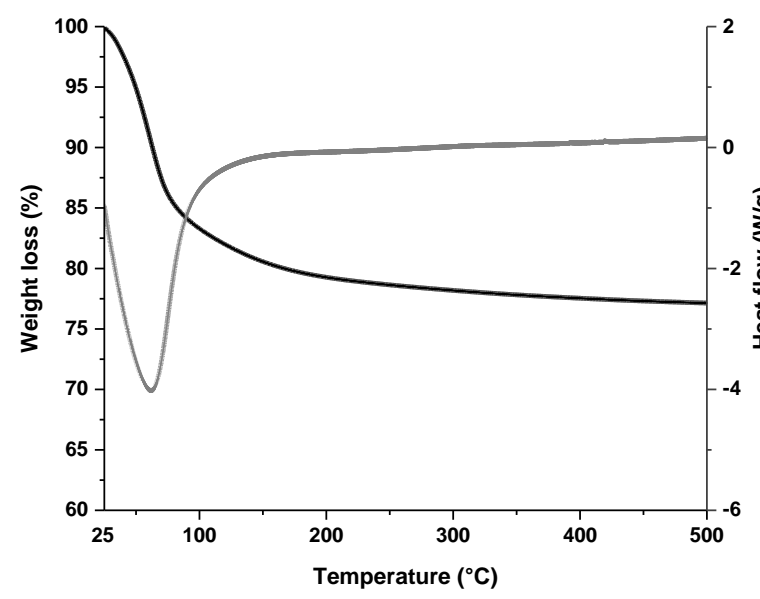

(b)

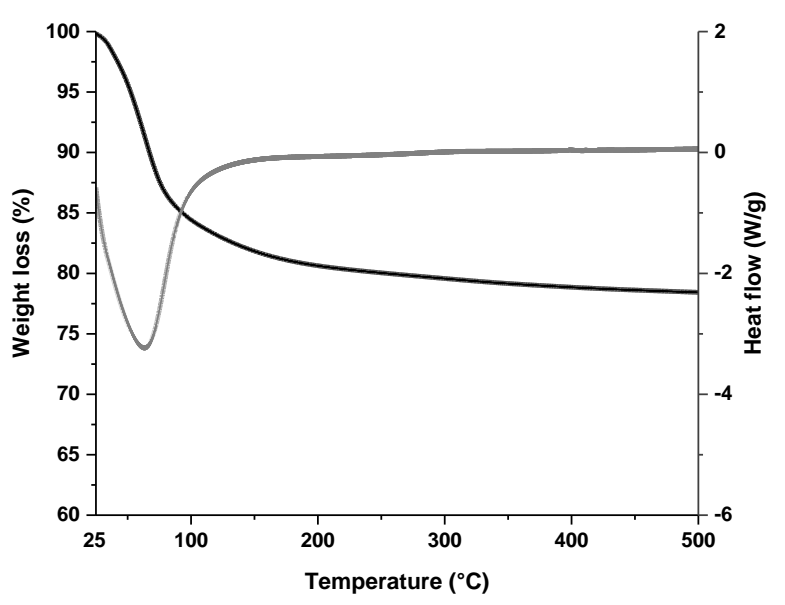

(c)

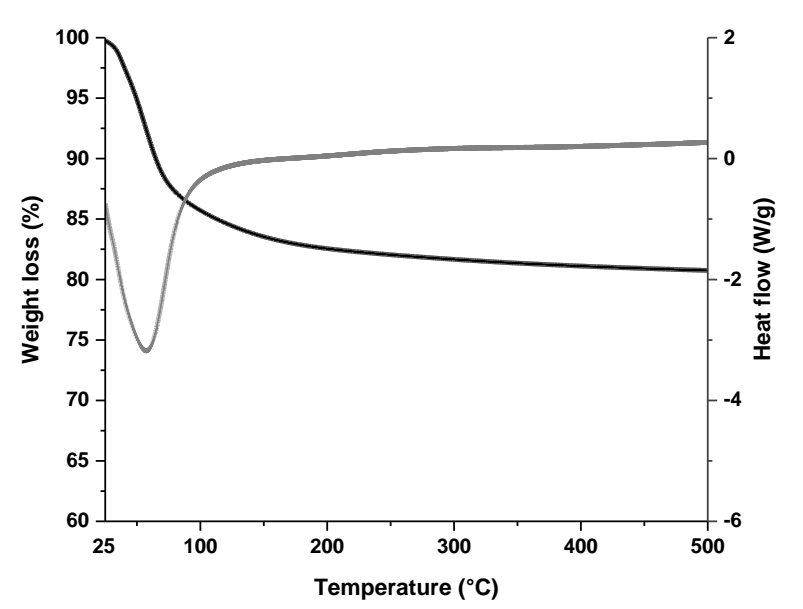

Figure 3: thermal analysis curves for the compositions (a) $\mathrm{M}_{16} \mathrm{~W}_{2} \mathrm{G}_{2}$, (b) $\mathrm{M}_{16} \mathrm{~W}_{10} \mathrm{G}_{2}$ and (c) $\mathrm{M}_{16} \mathrm{~W}_{21} \mathrm{G}_{2}$. 
(A)
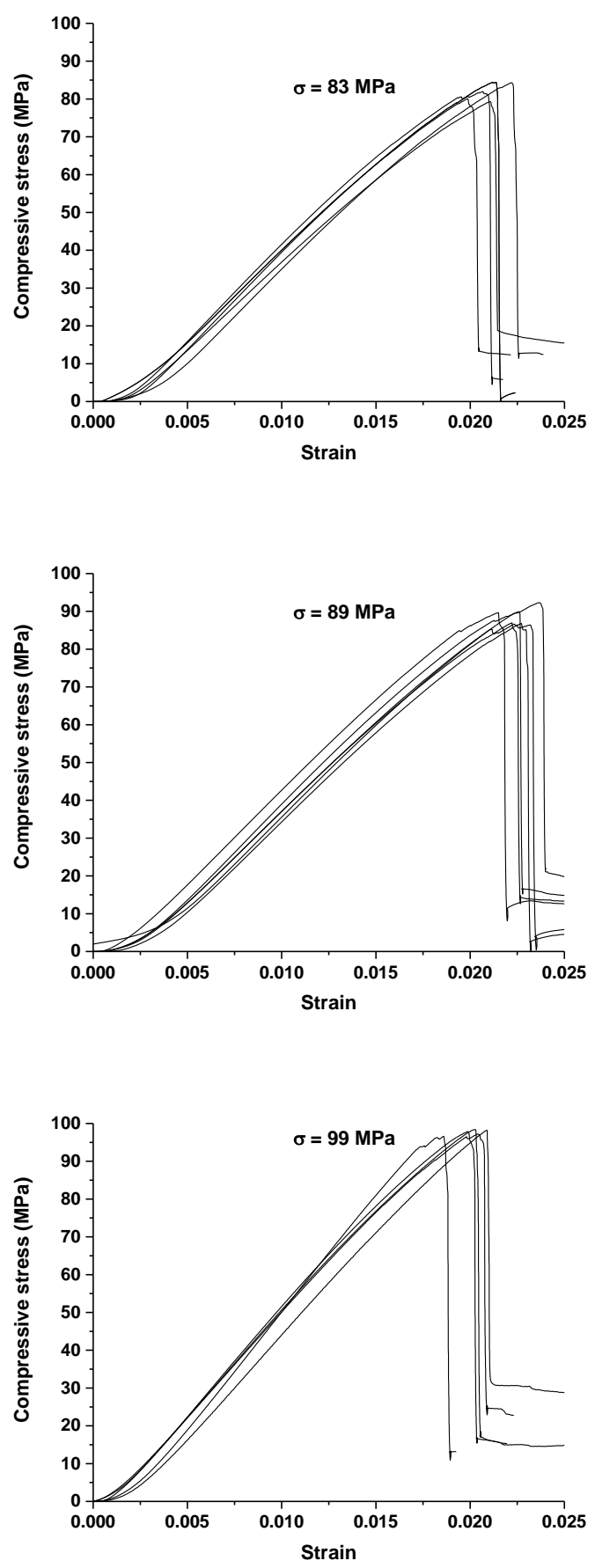

(B)

(a)

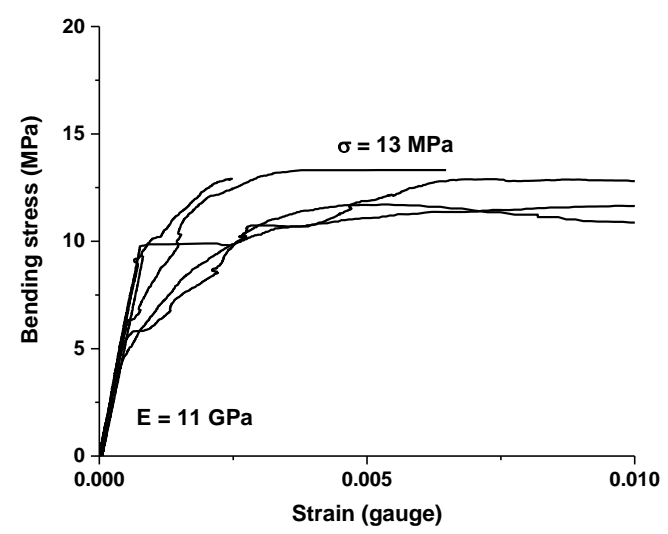

(b)

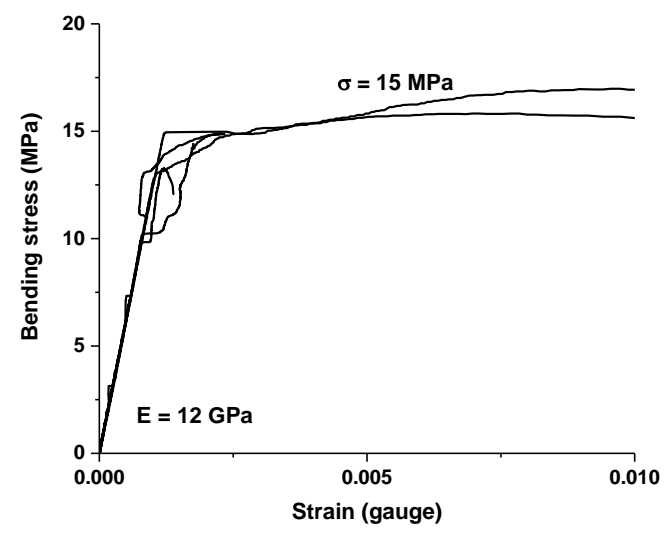

(c)

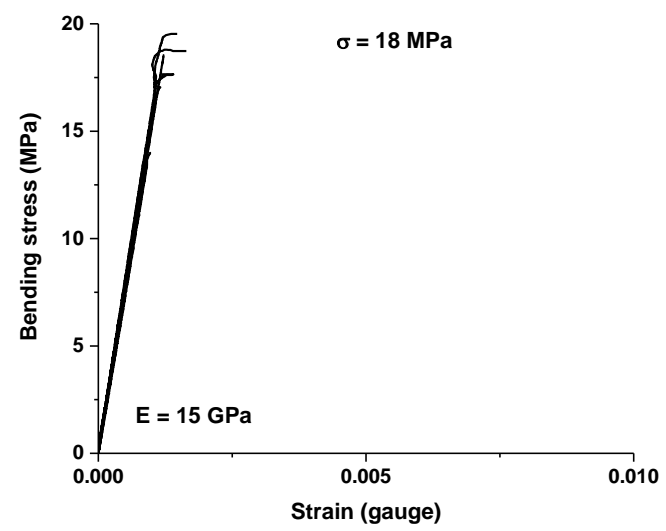

Figure 4: curves of the (A) compressive and (B) bending stress as a function of the strain for the compositions (a) $\mathrm{M}_{16} \mathrm{~W}_{2} \mathrm{G}_{2}$, (b) $\mathrm{M}_{16} \mathrm{~W}_{10} \mathrm{G}_{2}$ and (c) $\mathrm{M}_{16} \mathrm{~W}_{21} \mathrm{G}_{2}$. 


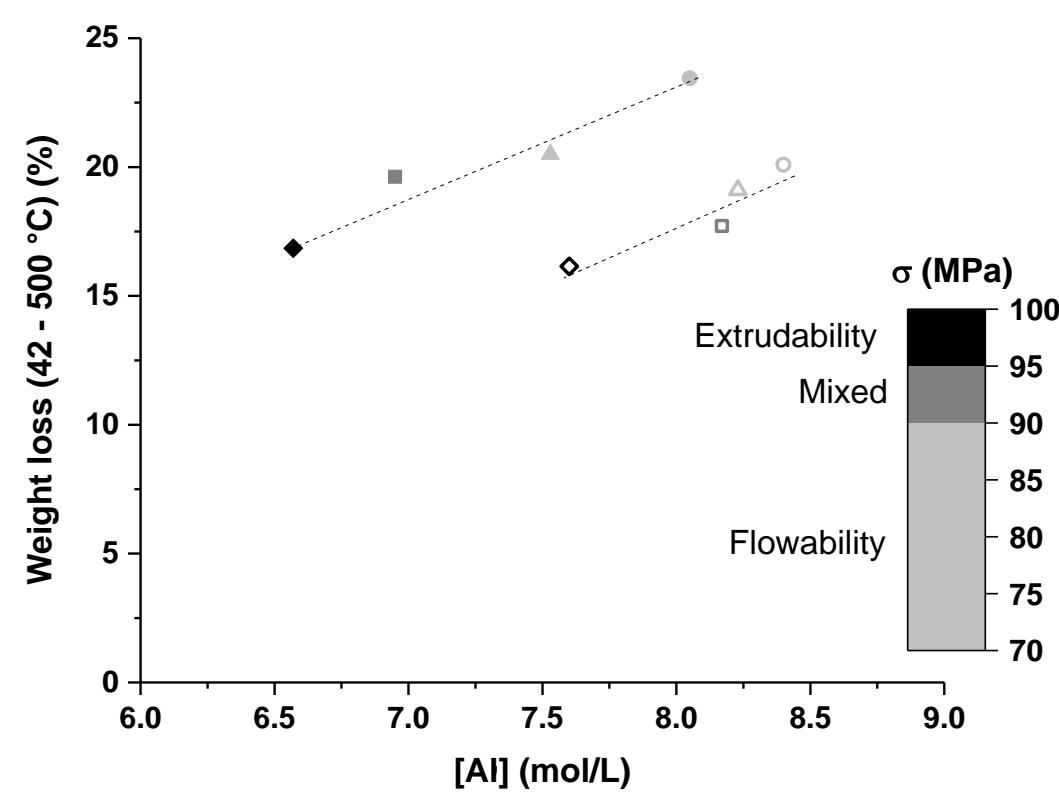

Figure 5: values of weight loss as a function of the aluminum concentration and the compressive stress of the composition $(\bullet, 0)$ a0, a0', $(\mathbf{\Delta}, \triangle)$ a, $\mathrm{a}^{\prime},(\boldsymbol{\square}, \square) \mathrm{b}, \mathrm{b}^{\prime}$, and $(\bullet, \diamond) \mathrm{c}, \mathrm{c}^{\prime}$. 


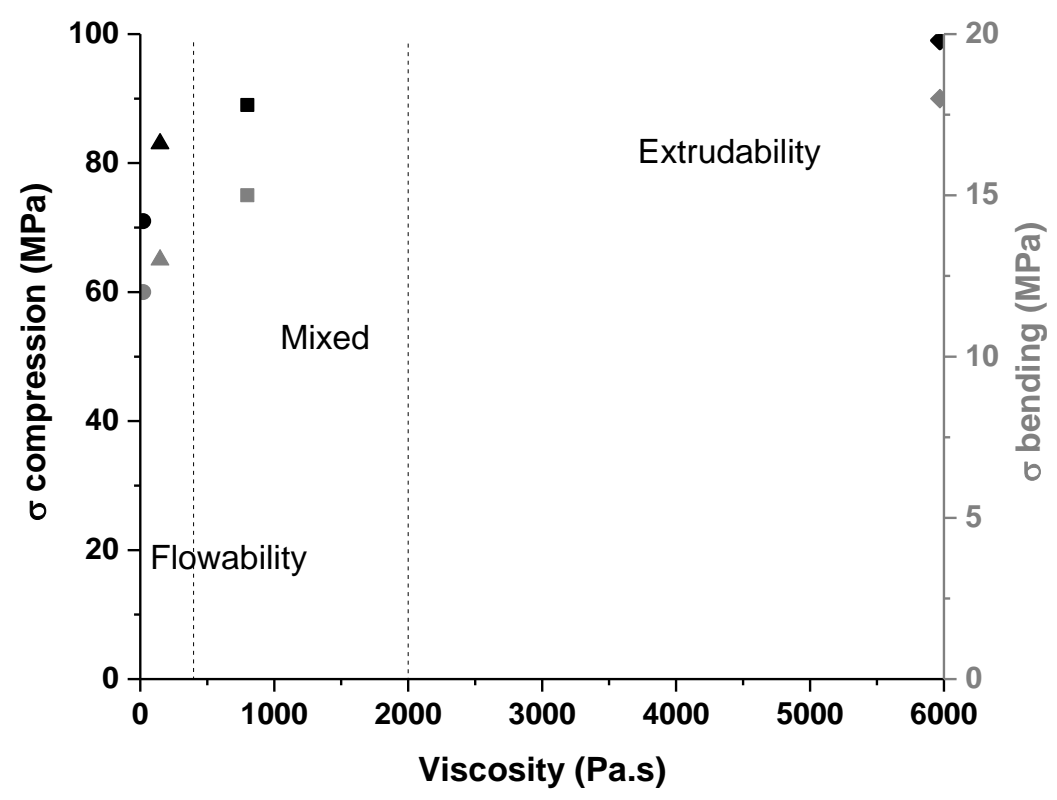

Figure 6: viscosity values as a function of $(\bullet)$ compressive and $(\bullet)$ bending stress for the compositions $(\bullet)$ a0, $(\boldsymbol{\Delta}) \mathrm{a},(\boldsymbol{\bullet}) \mathrm{b}$ et $(\bullet) \mathrm{c}$. 


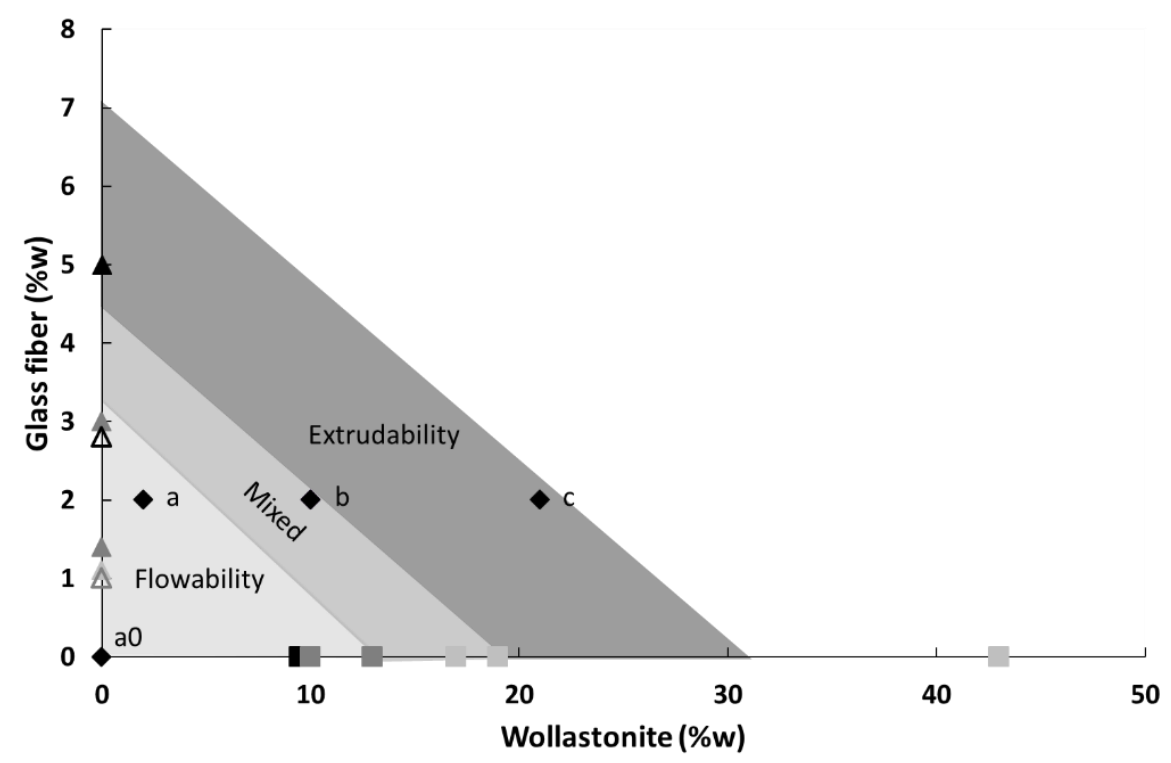

Figure 7: representation of the feasibility of shaping domains as a function of the weight percentage of ( $\boldsymbol{\square})$ wollastonite and ( $\Delta$ ) glass fibers for the $(\bullet)$ synthesized samples $\mathrm{M}_{16} \mathrm{~W}_{\mathrm{y}} \mathrm{G}_{\mathrm{z}}$ and the samples used in the literature with $(\square[34,52,53] \triangle[54])$ cements, $\left(\square\left[{ }^{35},{ }^{56}\right], \Delta\left[{ }^{55}, 57\right]\right)$ alkali-activated materials, $\left.\left(\boldsymbol{\square}^{58}\right], \boldsymbol{\Delta}[19]\right)$ geopolymers and $(\triangle[38,59])$ samples used in extrusion. 
Table 1: photos of the feasibility tests made with a syringe $\left(\Phi_{\text {nozzle }}=20 \mathrm{~mm}\right)$ to determine the shaping domains for the compositions $\mathrm{M} 1_{\mathrm{x}} \mathrm{W}_{\mathrm{y}}$ with $\mathrm{x}=10,14,16,19 \mathrm{~g}$.

\begin{tabular}{|c|c|c|}
\hline Domains & Casting & Extrusion \\
\hline y (\%) & $0-53$ & $53-68$ \\
\hline $\mathbf{M}_{10} W_{y}$ & & \\
\hline$y(\%)$ & 0 - 33 & $33-50$ \\
\hline $\mathbf{M}_{14} W_{y}$ & & \\
\hline$Y(\%)$ & 0 - 19 & $19-31$ \\
\hline $\mathbf{M}_{16} \mathbf{W}_{\mathbf{y}}$ & & \\
\hline $\mathbf{Y}(\%)$ & 0 - 8 & $8-14$ \\
\hline \multirow[t]{2}{*}{$\mathbf{M}_{19} \mathbf{W}_{\mathbf{y}}$} & & \\
\hline & & $2 \mathrm{~cm}$ \\
\hline
\end{tabular}


Table 2: photos of the compositions a0, a, b et c elaborated by casting and robocasting.

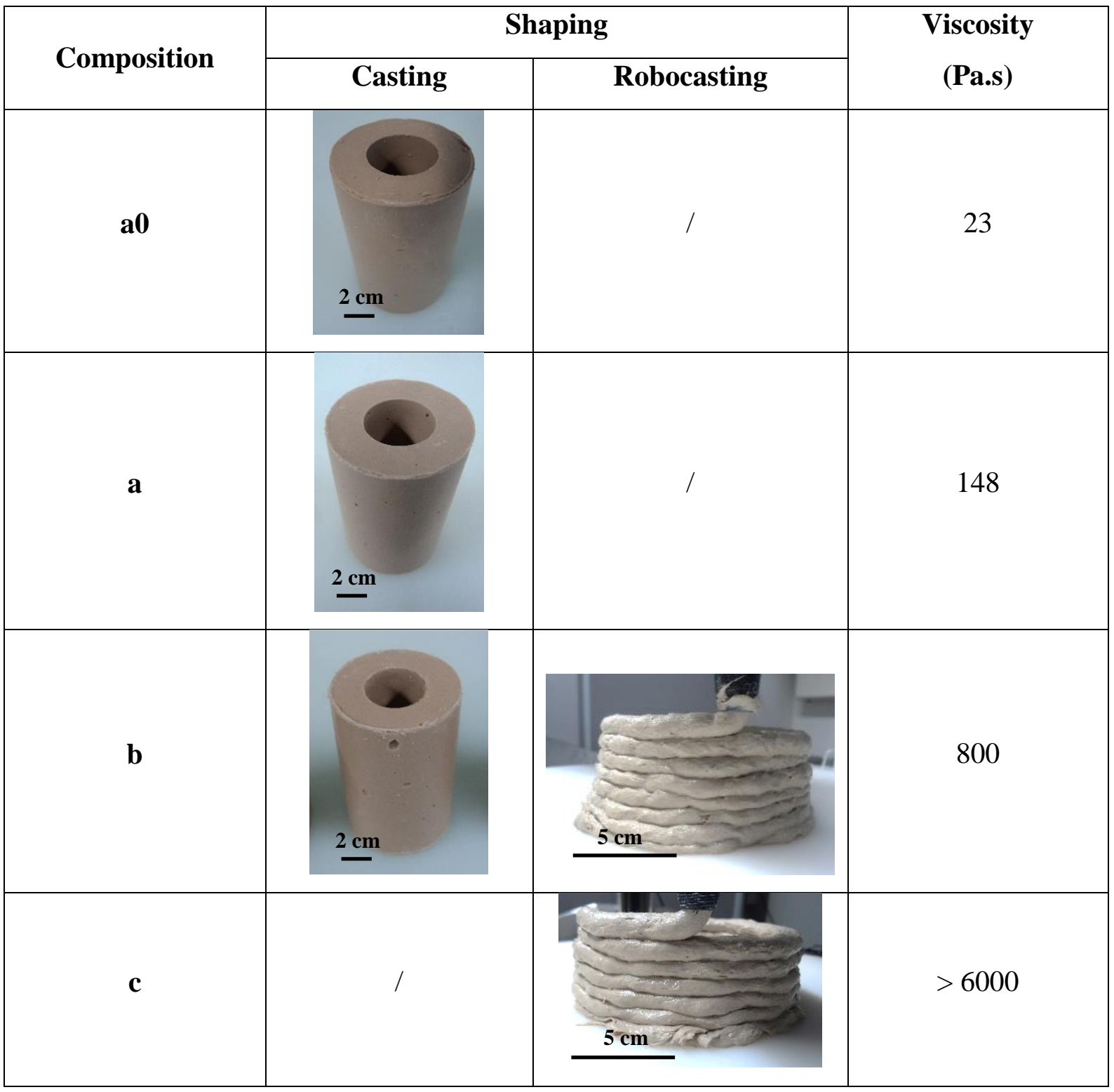




\section{REFERENCES}

[1] V.D. Glukhovsky, G.S. Rostovskaja, G.V. Rumyna, "Soil silicates". Gosstroyizdat, Kiev, 1959.

[2] J. Davidovits, "Geopolymers and geopolymeric materials", J. Therm. Anal., vol. 35, pp. 429-441, 1989, https://doi.org/10.1007/BF01904446.

[3] B. Panda, C. Unluer, M. J. Tan, "Extrusion and rheology characterization of geopolymer nanocomposites used in 3D printing", Composites part B, vol. 176, 107290, 2019, 10.1016/j.compositesb.2019.107290.

[4] M. Arnoult, M. Perronnet, A. Autef, S. Rossignol, "How to control the geopolymer setting time with the alkaline silicate solution", Journal of non-Crystalline Solids, vol. 495, pp. 59-66, 2018, 10.1016/j.jnoncrysol.2018.02.036.

[5] M. Romagnoli, P. Sassatelli, M. Lassinanti, Gualtieri, G. Tari, "Rheological characterization of fly-ash-based suspensions", Construction and Building Materials, vol. 65, pp. 526-534, 2014, https://doi.org/10.1016/j.conbuildmat.2014.04.130.

[6] M. Arnoult, M. Perronnet, A. Autef, S. Rossignol, "Geopolymer synthetized using reactive or unreactive aluminosilicate. Understanding of reactive mixture", Materials Chemistry and Physics, vol. 237, 121837, 2019, https://doi.org/10.1016/j.matchemphys.2019.121837.

[7] C. Dupuy, J. Havette, A. Gharzouni, N. Texier-Mandoki, X. Bourbon, S. Rossignol, "Metakaolin-based geopolymer: formation of new phases influencing the setting with the use of additives", Construction and Building Materials, vol. 200, pp. 272-281, 2019, https://doi.org/10.1016/j.conbuildmat.2018.12.114.

[8] S.H. Bong, B. Nematollahi, A. Nazari, M. Xia, J. Sanjayan, "Efficiency of different superplasticizers and retarders on properties of 'one part' fly ash-slag blended geopolymers with different activators", Materials, vol. $12,3410,2019,10.3390 / \mathrm{ma} 12203410$.

[9] B. Sri Umniati, P. Risdanareni, F. T. Z. Zein, "Workability enhancement of geopolymer concrete through the use of retarder", AIP Conference Proceedings, vol. 1887, 020033, 2017, 10.1063/1.5003516.

[10] R.A. Sé Ribeiro, M.G. Sà Ribeiro, W.M. Kriven, "A review of particle and fiber reinforced metakaolin based geopolymer composites", J. Ceram. Sci. Technol., vol. 08, pp. 302-322, 2017, 10.4416/JCST2017-00048.

[11] J.L. Provis, "Geopolymers. Structure, Processing", Properties and Industrial Applications, Woodhead Publishing Limited, 2009.

[12] H. Xu, J.S.J. Van Deventer, "The geopolymerization of alumino-silicate minerals", International Journal of Mineral Processing, vol. 59, pp. 247-266, 2000, https://doi.org/10.1016/S0301-7516(99)00074-5.

[13] T. Bakharev, "Thermal behaviour of geopolymers prepared using class-F fly ash and elevated temperature curing", Cement and Concrete Research, vol. 36, pp. 1134-1147, 2006, https://doi.org/10.1016/j.cemconres.2006.03.022.

[14] I. Capasso, I. Lirer, A. Flora, C. Ferone, R. Cioffi, D. Caputo, B. Liguori, "Reuse of mining waste as aggregates in fly ash-based geopolymers", Journal of Cleaner Production, vol. 220, pp. 65-73, 2019, https://doi.org/10.1016/j.jclepro.2019.02.164.

[15] C. Dupuy, A. Gharzouni, N. Texier-Mandoki, X. Bourbon, S. Rossignol, "Thermal resistance of argillitebased alkali-activated materials. Part I: effect of calcination processes and alkali cation", Materials Chemistry and Physics, vol. 217, pp. 323-333, 2018, https://doi.org/10.1016/j.matchemphys.2018.06.079.

[16] C. Dupuy, I. Sobrados, N. Tessier-Doyen, A. Gharzouni, N. Texier-Mandoki, X. Bourbon, S. Rossignol, "Formulation of an alkali-activated grout based on Callovo-Oxfordian argillite for an application in geological radioactive waste disposal", Construction and Building Materials, vol. 232, 117170, 2020, https://doi.org/10.1016/j.conbuildmat.2019.117170.

[17] M. Welter, M. Schmücker, K.J.D. MacKenzie, "Evolution of the fibre-matrix interactions in basalt-fibrereinforced geopolymer matrix composites after heating", J. Ceram. Sci. Tech., vol. 06, pp. 17-24, 2015, 10.4416/JCST2014-00034.

[18] E. Rill, D. Lowry, W.M. Kriven, "Properties of basalt fiber reinforced geopolymer composites", Strategic Materials and Computational Design, vol. 31, pp. 57-67, 2010, 10.13140/2.1.1763.3287.

[19] M. Steinerova, L. Matulova, P. Vermach, J. Kotas, "The Brittleness and chemical stability of optimized geopolymer composites", Materials, vol. 10, pp. 396-416, 2017, 10.3390/ma10040396.

[20] T. Sathanandam, P. O. Awoyera, V. Vijayan, K. Satishkumar, "Low carbon building : experimental insight on the use of fly ash and glass fiber for making geopolymer concrete", Sustainable Environment Research, vol. 27, pp. 146-153, 2017, https://doi.org/10.1016/j.serj.2017.03.005.

[21] F. Silva, C. Thaumaturgo, "Fibre reinforcement and fracture response in geopolymeric mortars", Fatigue fract. Enging. Mater. Struct., vol. 26, pp. 167-172, 2003, 10.1046/j.1460-2695.2003.00625.x.

[22] S. H. Bong, B. Nematollahi, M. Xia, A. Nazari, J.Sanjayan, "Properties of one-part geopolymer incorporating wollastonite as partial replacement of geopolymer precursor and sand", Materials letter, vol. 263, 127236, 2020, https://doi.org/10.1016/j.matlet.2019.127236. 
[23] J. Archez, N. Texier-Mandoki, X. Bourbon, J.F. Caron, S. Rossignol, "Influence of the wollastonite and glass fibers on geopolymer composites workability and mechanical properties", Construction and Building Materials, vol. 257, 119511, 2020, https://doi.org/10.1016/j.conbuildmat.2020.119511.

[24] J. Peyne, E. Joussein, J. Gautron, J. Doudeau, S. Rossignol, "Feasibility of producing geopolymer binder based on a brick clay mixture", Ceramics International, vol. 43, pp. 9860-9871, 2017, 10.1016/j.ceramint.2017.04.169.

[25] P. Chindaprasirt, T. Chareerat, V. Sirivivatnanon, "Workability and strength of coarse high calcium fly ash geopolymer", Cement and concrete composites, vol. 29, pp. 224-229, 2007, https://doi.org/10.1016/j.cemconcomp.2006.11.002.

[26] C. Chen, Q. Li , L. Shen, J.Zhai, "Feasibility of manufacturing geopolymer bricks using circulating fluidized bed combustion bottom ash", Environmental Technology, vol. 33, pp. 1313-1321, 2012, https://doi.org/10.1080/09593330.2011.626797.

[27] F. Huang, Z. Zhou, X. Cheng, "Properties of waste-based geopolymer building blocks", Applied Mechanics and Materials, vols. 357-360, pp. 935-938, 2013, https://doi.org/10.4028/www.scientific.net/AMM.357-360.935. [28] S. Wang, X. Ma, Z. Zhang, L. Li, Y. Li, "High strength inorganic-organic polymer composites (IOPC) manufactured by mold pressing of geopolymers", Construction and Building Materials, vol. 198, pp. 501-511, 2019, https://doi.org/10.1016/j.conbuildmat.2018.11.281.

[29] P. Koutnik, A. Soukup, P. Bezucha, J. Safar, J. Kohout, "Low viscosity metakaolinite based geopolymer binders", Construction and Building Materials, vol. 230, 116978, 2020, https://doi.org/10.1016/j.conbuildmat.2019.116978.

[30] V. Medri, E.Papa, J. Lizion, E. Landi, "Metakaolin-based geopolymer beads: Production methods and characterization", Journal of cleaner production, vol. 244, 118844, 2020, https://doi.org/10.1016/j.jclepro.2019.118844.

[31] J. Temuujin, A. Minjigmaa, W. Rickard, A. Van Riessen, "Thermal properties of spray coated geopolymer type compositions", J. Therm. Anal. Calorim., vol. 107, pp. 287-292, 2012, 10.1007/s10973-011-1766-4.

[32] J. Matthews, A. Sevakumar, S. Vaidya, W. Condit, "Large-Diameter Sewer Rehabilitation Using a SprayApplied Fiber-Reinforced Geopolymer Mortar", Pract. Period. Struct. Des. Constr., vol. 20, 04014050, 2015, 10.1061/(ASCE)SC.1943-5576.0000246.

[33] E. Mairitsch, H. Harmuth, "Composition and properties of a metakaolin-based geopolymer binder suitable for shaping using a slinger", Construction and building materials, vol. 156, pp. 277-283, 2017, 10.1016/j.conbuildmat.2017.08.164.

[34] T. Alomayri, "The microstructural and mechanical properties of geopolymer composites containing glass microfibers", Ceramics International, vol. $43, \quad$ pp. $4576-4582, \quad 2017$, https://doi.org/10.1016/j.ceramint.2016.12.118.

[35] A. M Soliman, M.L., Nehdi, "Effect of Natural Wollastonite Microfibers on Early-Age Behavior of UHPC", Journal of Materials in Civil Engineering, vol. 24, pp. 816-824, 2012, https://doi.org/10.1061/(ASCE)MT.19435533.0000473.

[36] L. Vickers, W.D.A. Rickard, A. van Riessen, "Strategies to control the high temperature shrinkage of fly ash based geopolymer" Thermochimica Acta, vol. 580, pp. 20-27, 2014, 10.1016/j.tca.2014.01.020.

[37] S. Lim, R.A. Buswell, S.A. Austin, A.G.F. Gibb, A. Thorpe, "Developments in construction-scale additive manufacturing processes", Automation in construction, vol. 21, pp. 261-268, 2012, https://doi.org/10.1016/j.autcon.2011.06.010.

[38] T.T. Le, S.A. Austin, S. Lim, R.A. Buswell, A.G.F. Gibb, A. Thorpe, "Mix design and fresh properties for high-performance printing concrete", Materials and Structures, vol. 45, pp. 1221-1232, 2012, https://doi.org/10.1617/s11527-012-9828-z.

[39] B. Panda, S. Paul, M. Jen Tan, "Anisotropic mechanical performance of 3D printed fiber reinforced sustainable construction material", Materials letters, vol. 209, pp. 146-149, 2017, https://doi.org/10.1016/j.matlet.2017.07.123.

[40] G. Franchin, P. Scanferla, L. Zeffiro, H. Elsayed, A. Baliello, G. Giacomello, M. Pasetto, P. Colombo, "Direct ink writing of geopolymeric inks", Journal of the European Ceramic Society, vol. 37, pp. 2481-2489, 2017, https://doi.org/10.1016/j.jeurceramsoc.2017.01.030.

$\left[{ }^{41}\right]$ S.H. Bong, B. Nematollahi, A. Nazari, M. Xia, J.G. Sanjayan, "Fresh and Hardened Properties of 3D Printable Geopolymer Cured in Ambient Temperature", 1st RILEM Bookseries, vol. 19, pp. 3-11, 2019.

$\left.{ }^{42}\right]$ S. C. Paul, Y.W.D. Tay, B. Panda, M.J. Tan, "Fresh and hardened properties of 3D printable cementitious materials for building and construction", Civil and Mechanical Engineering, vol. 18, pp. 311-319, 2018.

[43] V. N. Nerella, V. Mechtcherine, "Studying the Printability of Fresh Concrete for Formwork-Free Concrete Onsite 3D Printing Technology (CONPrint3D)", 3D Concrete Printing Technology, chapter 16, pp. 333- 347, 2019, 10.1016/B978-0-12-815481-6.00016-6.

[44] F. Bos, E. Bosco, T. A. M. Salet, "Ductility of 3D printed concrete reinforced with short straight steel fibers", Virtual and Physical Prototyping, vol. 14, pp. 160-174, 2019, https://doi.org/10.1080/17452759.2018.1548069. 
[45] S. C. Paul, Y.W.D. Tay, B. Panda, M.J. Tan, "Fresh and hardened properties of 3D printable cementitious materials for building and construction", Civil and Mechanical Engineering, vol. 18, pp. 311-319, 2018, https://doi.org/10.1016/j.acme.2017.02.008.

[46] B. Nematollahi, M. Xia, J. Sanjayan, P, Vijay, "Effect of type of fiber on inter-layer bond and flexural strengths of extrusion-based 3D printed geopolymer", Material Science Forum, vol. 939, pp. 155-162, 2018, 10.4028/www.scientific.net/MSF.939.155.

[47] B. Panda, S. C, Paul, N. A. N Mohamed, Y. W. D. Tay, M. J. Tan, , "Measurement of tensile bond strength of 3D printed geopolymer mortar", Measurement, vol. 103, pp. 108-116, 2018, https://doi.org/10.1016/j.measurement.2017.08.051.

[48] J.G. Sanjayan, B. Nematollahi, M. Xia, T. Marchment, "Effect of surface moisture on inter-layer strength of 3D printed concrete", Construction and building materials, vol. 172, pp. 468-475, 2018, https://doi.org/10.1016/j.conbuildmat.2018.03.232.

[49] S. Al-Qutaifi, A. Nazari, A. Bagheri, "Mechanical properties of layered geopolymer structures applicable in concrete 3D-printing", Construction and building materials, vol. 176, pp. 690-699, 2018, https://doi.org/10.1016/j.conbuildmat.2018.04.195.

[50] F. Bos, R. Wolfs, Z. Ahmed, T. Salet, "Additive manufacturing of concrete in construction: potentials and challenges of 3D concrete printing”, Virtual and physical prototyping, vol. 11, pp. 209-225, 2016, https://doi.org/10.1080/17452759.2016.1209867.

[51] A. Autef, E. Joussein, G. Gasgnier, S. Rossignol, "Role of the silica source on the geopolymerization rate: A thermal analysis study", Journal of Non-Crystalline Solids, vol. 366, pp. 13-21, 2013, doi:10.1016/j.jnoncrysol.2013.01.034.

[52] A. Gharzouni, E. Joussein, B. Samet, S. Baklouti, S. Rossignol, "Effect of the reactivity of alkaline solution and metakaolin on geopolymer formation", Journal of Non-crystalline Solids, vol. 410, pp. 127-134, 2015, 10.1016/j.jnoncrysol.2014.12.021.

[53] S.H. Bong, B. Nematollahi, A. Nazari, M. Xia, J.G. Sanjayan, "Fresh and Hardened Properties of 3D Printable Geopolymer Cured in Ambient Temperature", First RILEM International Conference on Concrete and Digital Fabrication, RILEM Bookseries, vol 19, 2019, https://doi.org/10.1007/978-3-319-99519-9_1.

[54] A. Kashani, T. Ngo, "Optimisation of Mixture Properties for 3D Printing of Geopolymer Concrete", Proceedings of the 35th ISARC, pp. 259-266, 2018, 10.22260/ISARC2018/0037.

[55] N. M. P. Low, J.J. Beaudoin, "Mechanical properties of high performance cement binders reinforced with wollastonite micro-fibres", Cement and concrete research, vol. 22, pp. 981-989, 1992, 10.1016/00088846(93)90044-A.

[56] R. N. Ransinchung, B. Kumar, "Investigations on Pastes and Mortars of Ordinary Portland Cement Admixed with Wollastonite and Microsilica", Journal of Materials in Civil Engineering, vol. 22, pp. 305-313, 2010, https://doi.org/10.1061/(ASCE)MT.1943-5533.0000019.

[57] A. B. Kizilkanat, N. Kabay, V. Akyüncü, S. Chowdhury, A. H. Akça, "Mechanical properties and fracture behavior of basalt and glass fiber reinforced concrete: An experimental study", Construction and Building Materials, vol. 100, pp. 218-224, 2015, https://doi.org/10.1016/j.conbuildmat.2015.10.006.

[58] R. Novais, J. Carvalheiras, M.P. Seabra, R.C. Pullar, J.A. Labrincha, "Effective mechanical reinforcement of inorganic polymers using glass fibre waste", Journal of Cleaner Production, vol. 166, pp. 343-349, 2017, 10.1016/j.jclepro.2017.07.242.

[59] D. Nurjaya, S. Astutiningsih, A. Zulfia, "Thermal effect on flexural strength of geopolymer matrix composite with alumina and wollastonite as fillers", International journal of technology, vol. 3, pp. 462-470, 2015, 10.14716/ijtech.v6i3.1441.

[60] B. Nematollahi, J. Sanjayan, J.X.H. Chai, T.M. Lu, "Properties of fresh and hardened glass fiber reinforced fly ash based geopolymer concrete", Key Engineering Materials, vol. 594-595, pp. 629-633, 2014, 10.4028/www.scientific.net/KEM.594-595.629.

[61] D. Ren, C. Yan, P. Duan, Z. Zhang, L. Li, Z. Yan, "Durability performances of wollastonite, tremolite and basalt fiber-reinforced metakaolin geopolymer composites under sulfate and chloride attack", Construction and $\begin{array}{llllll}\text { building } \quad \text { materials, } & \text { vol. } & 134, & \text { pp. } & 56-66, & 2017 \text {, }\end{array}$ https://www.sciencedirect.com/science/article/abs/pii/S0950061816320232.

[62] Z. Li, Y. Zhang, X, Zhou, "Short fiber reinforced geopolymer composites manufactured by extrusion", Journal of Materials in Civil Engineering, vol. 17, pp. 624-631, 2005, 10.1061/(ASCE)08991561(2005)17:6(624).

[63] L. Martinie, P. Rossi, N. Roussel, "Rheology of fiber reinforced cementitious materials: classification and prediction", Cement and concrete research, vol. 40, pp. 226-234, 2010, https://doi.org/10.1016/j.cemconres.2009.08.032.

[64] R.N. Swamy, P.S. Mangat, "Influence of fibre-aggregate interaction on some properties of steel fibre reinforced concrete", Materials and structures, vol. 7, pp. 307-314, 1974, https://doi.org/10.1007/BF02473840. 
